\title{
Spontaneous hemopneumothorax: experience with early surgical management of two clinics
}

\section{Spontan hemopnömotoraks: Erken cerrahi girişimde iki kliniğin tecrübeleri}

\author{
Alper Avci ${ }^{1}$, Serdar Onat ${ }^{2}$, Refik Ulku ${ }^{2}$, Cemal Ozcelik ${ }^{1}$
}

\author{
Cukurova University, Faculty of Medicine, Thoracic Surgery Department, Adana, Turkey \\ ${ }^{2}$ Dicle University, Faculty of Medicine, Thoracic Surgery Department, Diyarbakir, Turkey \\ Corresponding author: Alper Avci, MD, Cukurova University, Faculty of Medicine, Thoracic Surgery Department, Adana, Turkey \\ E-mail: dralperavci@mynet.com \\ Received/Accepted: January 07, 2019 /June 29, 2019 \\ Conflict of interest: There is not a conflict of interest.
}

\section{SUMMARY}

Objective: SHP is an uncommon clinical disorder that is potentially lifethreatening due to rapid lung collapse and blood loss into the pleural cavity. Early surgical intervention for SHP is a life-saving procedure, and avoids complications such as atelectasis, restrictive lung disorders, infection of residual hematoma and reduce the incidence of delayed surgical exploration and decortication. We herein report a retrospective study in order to evaluate our demographic records, intraoperative findings, surgical methods, and clinical experience of early surgery.

Method: We initially included all patients with primary spontaneous pneumothorax attending the clinics of Dicle University Faculty of Medicine, Diyarbakir, Turkey, and Cukurova UniversityFaculty of Medicine, Adana, Turkey. From June 2003 and December 2018, a total of 802 patients were diagnosed as spontaneous pneumothorax. After thoracocentesis, twenty-four of them were diagnosed with SHP of whom sixteen underwent a prompt thoracotomy or VATS. We retrospectively collected demographic characteristics, clinical presentations, admitting time intervals, initial chest tube drainage, surgical strategies, intraoperative findings, and medical history for all SHP patients.

Results: the Female / Male ratio was 1/23. I was ranging in age from 16 to 54 years (mean age, 25,6 years). Five patients underwent the urgent operation because of hypovolemic shock and amount of blood drainage. Other 11 patients underwent operation within 24 hours. Ten patients underwent thoracotomy, and 6 underwent VATS. Remain 8 patients were treated with tube thoracostomy. During the operations, the source of hemorrhage was detected; the aberrant apical vessel in 7 patients, torn of parietal pleura in 6 patients and ruptured vascularized bullae/lung parenchyma in 3 patients. No recurrence of SHP occurred with these 24 patients during the follow-up period.

Conclusions: Early surgery should be performed in patients who are hemodynamically unstable or continuous bleeding from the pleural drain. Both VATS and minithoracotomy are appropriate techniques for surgery. Keywords: Spontaneous hemopneumothorax, thoracic surgery, videoassisted surgery, thoracotomy
Alper Avci
(iD) Serdar Onat
(D) Refik Ulku
(D) Cemal Ozcelik

ORCID IDs of the authors: A.A. $0000-0001-9337-3030$ S.O. 0000-0021-4697-801 R.U. 0000-0015-7083-431 C.O. $0000-0001-7654-5523$ 
Amaç: Spontan hemopnömotoraks; nadir görülen ancak sebep olduğu akciğer kollapsı ve plevral aralığa kanama nedeni ile hayatı tehtid eden bir klinik durumdur. Erken cerrahi girişim hayat kurtarıcı olmasının yanında, atelektazi, rekstriktif akciğer hastalığı, hematom enfeksiyonunu, nüks ve ileri dönem dekortikasyon operasyonlarının önlenmesini sağlar. Bu retrospektif çalışma ile bu hastalarımızın demografik verilerini, intraoperatif bulgularımızı, cerrahi tekniklerimizi ve erken cerrahi konusundaki tecrübelerimizi paylaşmaktayız.

Yöntem: Haziran 2003 ile Aralık 2018 tarihleri arasında Dicle Üniversitesi ve Çukurova Üniversitesi Tip Fakülteleri Gögüs Cerrahisi kliniklerine başvuran 802 spontan pnömotoraks hastasının 24'e spontan hemopnömotoraks tanısı kondu. Bunlardan 16 tanesi VATS veya Torakotomi ile operasyona alındı. Retrospektif olarak bu hastaların demografik karakterleri, klinik semptomları ve süreleri, gögüs tüpü uygulanması verileri, cerrahi stratejileri, ameliyat içi bulgular ve anamnezleri değerlendirildi.

Bulgular: Kadın / Erkek oranı 1 / 23 idi. Yaş aralığı 16-54 arasında idi ( ortalama, 25,6 yaş). Hipovolemik şok ve fazla drenaj nedeni ile 5 hasta acil operasyona alınırken, 11 hastada ilk 24 saat içerisinde drenaj takibi sonrası operasyona alındı. On hastaya torakotomi, 6 hastaya VATS uygulanırken kalan 8 hasta göğüs tüpü uygulanması ile tedavi edildi. Ameliyat sırasında kanama kaynağı olarak; 7 hastada apikal aberan damar, 6 hastadaparietal plevra ve 3 hastada visseral plevra-bül saptandı. Takipler sırasında nüks SHP görülmedi.

Sonuç: Hemodinamik olarak stabil olmayan ve gögüs tüpü drenajı devamlı olan SHP hastalarında erken cerrahi uygulanmalıdır. Mini torakotomi ve VATS tekniklerinin her ikiside bu cerrahi için uygun girişimlerdir,

Anahtar sözcükler: Spontan hemopnömotoraks, gögüs cerrahisi, video yardımlı cerrahi, torakotomi

\section{INTRODUCTION}

Spontaneous hemopneumothorax (SHP) is a rare disorder. Historically, a hemothorax complicates $0,5-12 \%$ of spontaneous pneumothorax and potentially life-threatening condition. SHP occurs predominantly in adolescent and adult males ${ }^{1,2}$. It involves the accumulation of air and blood within the pleural space in the absence of trauma or other obvious causes. Major clinical features of SHP are chest pain, dyspnea, hypovolemia, and shock, which can be dramatic and depends on the amount of bleeding. Bleeding most commonly results from a torn small vessel located in adhesions between parietal and visceral pleura from the progress of lung collapse or rupture of a vascularised bulla ${ }^{3}$. The initial treatment of SHP is chest tube drainage, and prompt thoracotomy or video-assisted thoracoscopic surgery (VATS) may be required to achieve hemostasis. Surgical interventions such as thoracotomy and VATS have been valuable in decreasing the morbidity and mortality resulting from the use of more conservative treatment regimens ${ }^{2,3}$.

We herein report a retrospective study in order to evaluate our demographic records, intraoperative findings, surgical methods, and clinical experience of early surgery.

\section{MATERIAL AND METHODS}

We initially included all patients with primary spontaneous pneumothorax attending the clinics of Dicle University Faculty of Medicine,
Diyarbakir, Turkey, and Cukurova UniversityFaculty of Medicine, Adana, Turkey. From June 2003 and December 2018, a total of 802 patients were diagnosed as spontaneous pneumothorax. Forty-one of them presented spontaneous hydropneumothorax. After thoracocentesis, twenty-four of them (2.24\%) were diagnosed with SHP of whom sixteen underwent prompt thoracotomy or VATS.

We retrospectively collected demographic characteristics, clinical presentations, admitting time intervals, initial chest tube drainage, treatment strategies, and medical history for all SHP patients. In this study, spontaneous hemopneumothorax was defined as pneumothorax with concomitant accumulation of more than 400 $\mathrm{mL}$ of blood in the pleural cavity. Spontaneous hemopneumothorax was estimated based on the following criteria; a) an otherwise healthy individual without related history or underlying disease, b) chest radiographic images showing spontaneous pneumothorax associated with an increased air-fluid level, and c) the absence of natural or iatrogenic trauma to the lung or pleural space within 48 hours ${ }^{4}$. The final SHP diagnosis was established via thoracocentesis.

Sixteen of twenty-four SHP patients underwent prompt thoracotomy or VATS within 24 hours. Indications for the operation were a hypovolemic shock, more than $1000 \mathrm{ml}$ initial chest tube drainage, continuous bleeding $(200 \mathrm{ml} / \mathrm{h}$ for 4 hours and $100 \mathrm{ml} / \mathrm{h}$ for 8 hours), persistent air leak, impaired lung expansion. 
Surgical technique: general anesthesia was performed using single-lung ventilation with a double-lumen endotracheal tube. The patient was placed in a lateral decubitus position. The limited posterolateral incision was created and fourth intercostal space used to enter pleural cavity for thoracotomy and camera port at 7.th intercostal space midaxillary line with a $3 \mathrm{~cm}$ working incision at the 4 the anterior axillary line for VATS. First, the bleeding point was found and stopped by electronic coagulation or ligation as soon as possible. Next, blood clots were evacuated using a sucker, and the ruptured bullae were resected with a stapler. In cases which any bullae or blebs were not seen, apical parenchymal wedge resection was applied with staples. Mechanical pleural abrasion was also applied to all patients to avoid recurrences. Then, the lung was allowed to re-inflate and tested for air leakage under water. A chest tube was inserted and placed before closing incision.

\section{RESULTS}

Demographic and clinical characteristics of 24 patients with SHP were shown in Table 1. Female / Male ratio was 1/23. Ranging in age from 16 to 54 years (mean age, 25,6 years). Sudden onset of chest pain and dyspnea were the most common initial symptoms. All patients had pneumothorax and air-fluid line on plain chest x-rays. Fifteen patients had no remarkable medical respiratory history. Subsequent SHPs were confirmed by thoracentesis followed by tube thoracostomy for removal of blood and air in the pleural cavity. Five patients underwent the urgent operation because of hypovolemic shock and amount of blood drainage. Other 11 patients underwent operation within 24 hours, according to the continuing blood drainage. Indications for operation were a hypovolemic shock, more than $1000 \mathrm{ml}$ initial chest tube drainage, continuous bleeding $(200 \mathrm{ml} / \mathrm{h}$ for 4 hours, and $100 \mathrm{ml} / \mathrm{h}$ for 8 hours). Ten patients underwent thoracotomy, and 6 underwent VATS. Remain 8 patients were treated with tube thoracostomy. There were 11 left sided operations and 5 right sided operations. There was no bilateral SHP.

During the operations, the source of hemorrhage was detected; the aberrant apical vessel in 7 patients, torn of parietal pleura in 6 patients and ruptured vascularized bullae/lung parenchyma in 3 patients. Aberrant vessels and parietal pleural torn bleeding were controlled by clipping or directly coagulating. Ruptured bullies and parenchymal tears were controlled by resections with parenchymal staples.

After detection, visible bullies were resected. In cases which any bullae or blebs were not seen, apical parenchymal wedge resection was applied with a stapler. Mechanical pleural abrasion was also applied to all patients to avoid recurrences.

All patients had an uneventful recovery period. Postoperative chest tube drainage durations were; 4,1 days for VATS, 5,4 days for tube thoracostomy and 5,8 days for thoracotomy patients. Mean hospital stay time was 6,1 days. No recurrence of SHP occurred with these 24 patients during the follow-up period ( range, 5 to 167 months). 
Table 1: Demographic and operative findings of the patients

\begin{tabular}{|c|c|c|c|c|c|c|c|c|c|}
\hline Case & $\begin{array}{l}\text { Age/ } \\
\text { Gender }\end{array}$ & $\begin{array}{l}\text { Medical } \\
\text { history }\end{array}$ & Symptoms & $\begin{array}{l}\text { Admitting } \\
\text { time interval }\end{array}$ & $\begin{array}{l}\text { Side/lung } \\
\text { collapse }\end{array}$ & Shock & Treatment & $\begin{array}{l}\text { Drained/Aspirate } \\
\mathrm{d} \text { blood }(\mathrm{mL})\end{array}$ & $\begin{array}{l}\text { Source of } \\
\text { Bleeding }\end{array}$ \\
\hline 1 & $46 / M$ & None & Chest pain & 3 hours & $\begin{array}{l}\text { Right / } \\
\text { Severe }\end{array}$ & No & Thoracotomy & 900 & Parietal pleura \\
\hline 2 & $26 / F$ & & $\begin{array}{l}\text { Chest pain, } \\
\text { dyspnea }\end{array}$ & 3 hours & $\begin{array}{l}\text { Left / } \\
\text { Moderate }\end{array}$ & No & Thoracotomy & 850 & $\begin{array}{l}\text { Visseral pleura - } \\
\text { Bullae/bleb }\end{array}$ \\
\hline 3 & $26 / M$ & None & $\begin{array}{l}\text { Chest Pain, } \\
\text { dyspnea }\end{array}$ & 2 hours & $\begin{array}{l}\text { Left / } \\
\text { Severe }\end{array}$ & Yes & Thoracotomy & 1100 & Aberrant vessel \\
\hline 4 & $54 / M$ & $\begin{array}{l}\text { Left } \\
\text { bullae }\end{array}$ & $\begin{array}{l}\text { Chest pain, } \\
\text { back pain }\end{array}$ & 1 hour & $\begin{array}{l}\text { Left / } \\
\text { Moderate }\end{array}$ & No & $\begin{array}{l}\text { Tube } \\
\text { thoracostomy }\end{array}$ & 450 & \\
\hline 5 & $16 / M$ & None & Dyspnea & 4 hours & $\begin{array}{l}\text { Left / } \\
\text { Severe }\end{array}$ & No & Thoracotomy & 800 & Parietal pleura \\
\hline 6 & $24 / M$ & None & Chest pain & 2 hours & $\begin{array}{l}\text { Left / } \\
\text { Moderate }\end{array}$ & No & Thoracotomy & 1200 & Aberrant vessel \\
\hline 7 & $24 / M$ & None & $\begin{array}{l}\text { Chest pain, } \\
\text { dyspnea }\end{array}$ & 4 hours & $\begin{array}{l}\text { Left / } \\
\text { Severe }\end{array}$ & No & Thoracotomy & 900 & Parietal pleura \\
\hline 8 & $31 / M$ & $\begin{array}{l}\text { Bullous } \\
\text { disease }\end{array}$ & $\begin{array}{l}\text { Chest pain, } \\
\text { dyspnea }\end{array}$ & 30 minutes & $\begin{array}{l}\text { Left / } \\
\text { Moderate }\end{array}$ & Yes & Thoracotomy & 1500 & $\begin{array}{l}\text { Visseral pleura - } \\
\text { Bullae/bleb }\end{array}$ \\
\hline 9 & $27 / M$ & None & Chest pain & 2 hours & $\begin{array}{l}\text { Left / } \\
\text { Severe }\end{array}$ & No & $\begin{array}{l}\text { Tube } \\
\text { thoracostomy }\end{array}$ & 650 & \\
\hline 10 & $25 / M$ & None & $\begin{array}{l}\text { Chest pain, } \\
\text { back pain }\end{array}$ & 3 hours & $\begin{array}{l}\text { Right / } \\
\text { Moderate }\end{array}$ & No & Thoracotomy & 750 & Parietal pleura \\
\hline 11 & $19 / \mathrm{M}$ & $\begin{array}{l}\text { Left } \\
\text { bullae }\end{array}$ & Chest Pain & 2 hours & $\begin{array}{l}\text { Left / } \\
\text { Moderate }\end{array}$ & No & $\begin{array}{l}\text { Tube } \\
\text { thoracostomy }\end{array}$ & 500 & \\
\hline 12 & $23 / M$ & None & Dyspnea & 4 hours & $\begin{array}{l}\text { Right / } \\
\text { Moderate }\end{array}$ & No & $\begin{array}{l}\text { Tube } \\
\text { thoracostomy }\end{array}$ & 700 & \\
\hline 13 & $20 / M$ & $\begin{array}{l}\text { Right } \\
\text { Bullae }\end{array}$ & $\begin{array}{l}\text { Chest pain, } \\
\text { dyspnea }\end{array}$ & 1 hour & $\begin{array}{l}\text { Right / } \\
\text { Moderate }\end{array}$ & No & VATS & 1000 & Aberrant vessel \\
\hline 14 & $31 / M$ & None & $\begin{array}{l}\text { Back Pain, } \\
\text { Dyspnea }\end{array}$ & 3 hours & $\begin{array}{l}\text { Left / } \\
\text { Severe }\end{array}$ & No & $\begin{array}{l}\text { Tube } \\
\text { thoracostomy }\end{array}$ & 900 & \\
\hline 15 & $22 / M$ & None & Chest Pain & 5 hours & $\begin{array}{l}\text { Left / } \\
\text { Moderate }\end{array}$ & No & Thoracotomy & 1100 & Aberrant vessel \\
\hline 16 & $26 / M$ & $\begin{array}{l}\text { Bullous } \\
\text { disease }\end{array}$ & Chest Pain & 2 hours & $\begin{array}{l}\text { Right / } \\
\text { Moderate }\end{array}$ & No & $\begin{array}{l}\text { Tube } \\
\text { thoracostomy }\end{array}$ & 600 & \\
\hline 17 & $17 / M$ & None & $\begin{array}{l}\text { Chest pain, } \\
\text { dyspnea }\end{array}$ & 1 hour & $\begin{array}{l}\text { Left / } \\
\text { Severe }\end{array}$ & Yes & VATS & 1200 & Aberrant vessel \\
\hline 18 & $25 / M$ & $\begin{array}{l}\text { Left } \\
\text { bullae }\end{array}$ & $\begin{array}{l}\text { Chest pain, } \\
\text { dyspnea }\end{array}$ & 45 minutes & $\begin{array}{l}\text { Left / } \\
\text { Severe }\end{array}$ & No & VATS & 900 & Aberrant vessel \\
\hline 19 & $19 / \mathrm{M}$ & None & $\begin{array}{l}\text { Chest pain, } \\
\text { dyspnea }\end{array}$ & 2 hours & $\begin{array}{l}\text { Left / } \\
\text { Moderate }\end{array}$ & No & Thoracotomy & 1000 & Parietal pleura \\
\hline 20 & $19 / \mathrm{M}$ & None & ChestPain & 4 hours & $\begin{array}{l}\text { Right/ } \\
\text { Severe }\end{array}$ & No & VATS & 900 & \\
\hline 21 & $23 / M$ & $\begin{array}{l}\text { Left } \\
\text { bullae }\end{array}$ & Dyspnea & 1 hour & $\begin{array}{l}\text { Left / } \\
\text { Moderate }\end{array}$ & No & VATS & 950 & Parietal pleura \\
\hline 22 & 17 / M & None & $\begin{array}{l}\text { Chest pain, } \\
\text { dyspnea }\end{array}$ & 3 hours & $\begin{array}{l}\text { Left / } \\
\text { Severe }\end{array}$ & No & $\begin{array}{l}\text { Tube } \\
\text { thoracostomy }\end{array}$ & 450 & \\
\hline 23 & $27 / M$ & $\begin{array}{l}\text { Bullous } \\
\text { disease }\end{array}$ & $\begin{array}{l}\text { Chest pain, } \\
\text { dyspnea }\end{array}$ & 2 hours & $\begin{array}{l}\text { Right / } \\
\text { Moderate }\end{array}$ & No & VATS & 1100 & Aberrant vessel \\
\hline 24 & $29 / M$ & None & Dyspnea & 5 hours & $\begin{array}{l}\text { Left / } \\
\text { Moderate }\end{array}$ & No & $\begin{array}{l}\text { Tube } \\
\text { thoracostomy }\end{array}$ & 850 & \\
\hline
\end{tabular}

\section{DISCUSSION}

SHP is an uncommon clinical disorder that is potentially life-threatening due to rapid lung collapse and blood loss into pleural cavity ${ }^{5}$. SHP is found in $1 \%-12 \%$ of patients presenting with spontaneous pneumothorax ${ }^{6}$. In our study, SHP was seen $2,24 \%$ of spontaneous pneumothorax patients and occurred predominantly in adolescent and adult males. As we used, chest $\mathrm{x}$-ray radiography remains the most useful investigation for diagnosis of the condition. The exact diagnosis of SHP is done with thoracentesis or chest tube insertion. We noted most common initial symptoms were chest pain and dyspnea, which were similar to literature ${ }^{1-5}$. The patient would be 
at risk of massive blood loss in SHP. The source of bleeding in SHP can be due to a small noncontractile vessel in the area of a torn vascular adhesion, rupture of vascular bullae, or an aberrant vessel that is usually thin-walled and does not contract adequately due to a lack of muscle fibers ${ }^{7}$. In our study, the source of hemorrhage was detected; the aberrant apical vessel in 7 patients, torn of parietal pleura in 6 patients and ruptured vascularized bullae/lung parenchyma in 3 patients. We performed 5 emergency surgery when patients hemodynamic instability. Other 11 patients underwent surgery in a day due to continuing drainage. Early surgical intervention for SHP also avoids complications such as atelectasis, restrictive lung disorders, infection of residual hematoma ${ }^{8}$. Early surgery also can reduce the incidence of delayed surgical exploration and decortication. A conservative approach with tube thoracostomy can be used in a selected group of patients whose bleeding will usually subside within 24 hours ${ }^{9}$. We advocate tube thoracostomy alone when patients do not present with any of the emergency or early surgery indications. In our series, most patients underwent an operation with a minithoracotomy. Additionally, 6 patients were treated with VATS. Effectively solving the problem of bleeding and removing blood clots, resection of blebs or bullae and performing pleurodesis under direct vision with minimal trauma and reduced postoperative pain and hospital costs make VATS widely accepted technique by thoracic surgeons.

The rate of recurrence of spontaneous pneumothorax is reported to range from $3 \%$ to $8.3 \%$ in the literature ${ }^{10}$. We did not determinate any recurrence of SHP in our series. We think that mechanical intraoperative pleural abrasion and minimal residual blood clots within the pleural space may have caused substantial pleurodesis, which prevented subsequent attacks.

\section{CONCLUSION}

SHP is a rare clinical disorder that can lead to potentially life-threatening complications. Early surgery should be performed in patients who are hemodynamically unstable or continuous bleeding from the pleural drainage system. Both VATS and minithoracotomy are appropriate techniques for surgery. Patients who do not have surgery indications can be treated with tube thoracostomy alone.

\section{REFERENCES}

1.Abyholm EE, Storen G. Spontaneous haemopneumothorax. Thorax 1973; 28: 376-7.

2. Tatebe Sh, Kanazawa H, Yamazaki Y, Aoki E, Sakurai Y. Spontaneous hemopneumothorax. Ann Thorac Surg 1996; 62: 1011-5.

3.Rowell NR. Spontaneous haemopneumothorax. Br J Tuberc 1956; 50: 214-20.

4.Wu YC, Lu MS, Yeh $\mathrm{CH}$, et al. Justifying video-assisted thoracic surgery for spontaneous hemopneumothorax. Chest 2002; 122: 1844-7.

5.Chiang WC, Chen WJ, Chang KJ, Lai TI, Yuan A. Spontaneous hemopneumothorax: an overlooked life-threatening condition. Am J Emerg Med 2003; 21: 343-5.

6.Ali HA, Lippmann M, Mundathaje U, Khaleeq G. Spontaneous hemothorax: a comprehensive review. Chest 2008; 134: 1056-65.

7. Kurimoto Y, Hatamoto K, Hase M, Narimatsu E, Asai Y, Abe T. Aberrant artery as a source of bleeding in spontaneous hemopneumothorax. Am J Emerg Med 2001; 19: 326-7.

8.Kim ES, Kang JY, Pyo CH, Jeon EY, Lee WB. A 12-year experience of spontaneous hemopneumothorax. Ann Thorac Cardiovasc Surg 2008; 14: 149-53.

9.De Perrot M, Deieaval J, Robert J, Spiliopoulos A. Spontaneous Hemopneumothorax -results of concervative treatment. Swiss Surg 2000; 6: 62-4. 10.Hsu NY, Shih CS, Hsu CP, Chen PR. Spontaneous hemopneumothorax revisited: Clinical approach and systemic review of the literatüre. Ann Thorac Surg 2005; 80: 1859-63. 